\title{
Уголовно-процессуальный кодекс Российской Федерации: оценка эфрфективности и меры по его совершенствованию
}

\author{
Б. Я. ГАВРИЛОВ \\ Академия управления МВД России, г. Москва, Российская Федерация \\ ORCID: https://orcid.org/0000-0002-2529-491X, e-mail: profgavrilov@yandex.ru
}

Р е ферат

Введение: статья посвящена анализу положений Уголовно-процессуального кодекса Российской Федерации и его влиянию наэффективность реализации государством в лице правоохранительных и судебных органов основных правовых институтов, призванных обеспечить соблюдение прав и законных интересов участников уголовного судопроизводства. Цель: на основе исследования эффективности внесенных в кодекс изменений и статистического анализа результатов расследования уголовных дел показаны выявленные научным сообществом и правоприменительной практикой недостатки законодательства в данной сфере деятельности и одновременно предложены меры по совершенствованию как отдельных правовых норм УПК РФ, так и ряда его процессуальных институтов по обеспечению конституционных установлений о защите государством прав и свобод человека и гражданина. Методы: исторический, сравнительно-правовой и эмпирические методы описания вопросов качества и законности при расследовании уголовных дел; теоретические методы формальной и диалектической логики. Применялись частно-научные методы: юридико-технический и метод толкования конкретных правовых норм. Результаты: анализ развития российского и зарубежного уголовно-процессуального законодательства и правоприменительной практики объективно свидетельствует о том, что абсолютное большинство внесенных в кодекс изменений способствовало повышению эффективности деятельности должностных лиц органов предварительного расследования и органов дознания по реализации положений ст. 6 , провозглашающей в качестве назначения (задачи) уголовного судопроизводства защиту как прав и законных интересов пострадавших от преступлений граждан и организаций, так и личности от незаконного уголовного преследования, осуждения и иных ограничений ее прав и свобод. Совершенствование уголовно-процессуального законодательства направлено также на преодоление заформализованности его отдельных положений и забюрократизированности действий следователя, дознавателя, органов прокуратуры и судейского сообщества при расследовании и судебном разбирательстве уголовных дел. Выводы: для адаптации российского уголовного процесса к современным реалиям (новые виды преступлений и способов их совершения, возросшие требования к обеспечению законности в деятельности органов предварительного расследования, соблюдению ими процессуальных сроков по уголовным делам и повышению качества их расследования и др.) необходима существенная трансформация досудебной стадии производства, заключающаяся в реорганизации процессуальных правил начала производства по уголовному делу, приведении сроков расследования в соответствие с положениями ст. 61 УПК РФ о разумном сроке уголовного судопроизводства, дальнейшей дифференциации форм расследования и др., что направлено на повышение эффективности борьбы с преступностью и ее наиболее опасными видами.

Ключевые слова: досудебное производство; уголовное дело; процессуальные сроки; законность и качество расследования; совершенствование законодательства.

12.00.09 - Уголовный процесс.

Для цитиров ания: Гаврилов Б. Я. Уголовно-процессуальный кодекс Российской Федерации: оценка эффективности и меры по его совершенствованию. Пенитенциарная наука, 2021, т. 15, № 4 (56), с. 753-765. DOI 10.46741/2686-97642021-15-4-753-765. 


\title{
Criminal Procedural Code of the Russian Federation: evaluation of effectiveness and measures for its improvement
}

\author{
BORIS YA. GAVRILOV \\ Academy of Management of the Ministry of Internal Affairs of Russia, Moscow, \\ Russian Federation \\ ORCID: https://orcid.org/0000-0002-2529-491X, e-mail: profgavrilov@yandex.ru
}

\begin{abstract}
Introduction: the article analyzes provisions of the Criminal Procedural Code of the Russian Federation and its impact on the implementation of key legal institutions designed to ensure respect for the rights and legitimate interests of criminal proceedings participants by law enforcement and judicial authorities. Purpose: having studied effectiveness of the amendments made in the CPC and conducted statistical analysis of the results of criminal cases investigation, the author presents shortcomings in the legislation identified by the scientific community and law enforcement practice and proposes measures to improve both certain legal norms of the CPC RF and its procedural institutions in order to ensure constitutional provisions on the state protection of human and civil rights and freedoms. Methods: the researcher used historical, comparative legal and empirical methods for describing quality and legality issues in the investigation of criminal cases; theoretical methods of formal and dialectical logic. Private scientific and legal technical methods, as well as the method for interpreting specific legal norms were applied. Results: the analysis of development of Russian and foreign criminal procedural legislation and law enforcement practice objectively indicates that the absolute majority of the amendments made to the Code contributed to enhancing performance of pre-trial investigation or initial inquiry bodies in implementing the provisions of Article 6 of the CPC. It stipulates protection of the rights and lawful interests of the persons and organizations, who (which) have suffered from the crimes, as well as their protection from unlawful accusations and conviction, and other restrictions of their rights and freedoms. Betterment of the criminal procedural legislation is also aimed at overcoming formalization of its individual provisions and bureaucratization of actions of the inquirer, investigator, prosecutor's office and judicial community in the investigation and trial of criminal cases. Conclusions: to adapt the modern Russian criminal process to modern realities (new types of crimes and methods of their commission, increased requirements for ensuring legality in activities of pre-trial investigation bodies, their compliance with procedural deadlines in criminal cases and improving investigation quality) it is necessary to make changes in pre-trial proceedings, in particular, to reorganize procedural rules for commencement of criminal proceedings; bringing investigation terms into line with the provisions of Article 61 of the $\mathrm{CPC}$ on a reasonable period of criminal proceedings; differentiating investigation forms, etc. All this is focused on improving effectiveness of the fight against crime and its most dangerous types.
\end{abstract}

Ke y w ord s: pre-trial proceedings; criminal case; procedural deadlines; legality and quality of investigation; improvement of legislation.

\subsubsection{9 - Criminal process.}

F or c it ati o n: Gavrilov B.Ya. Criminal Procedural Code of the Russian Federation: evaluation of effectiveness and measures for its improvement. Penitentiary Science, 2021, vol. 15, no. 4 (56), pp. 753-765. DOI 10.46741/2686-9764-2021-15-4-753-765.

С учетом внесенных в УПК РФ за двадцать лет его действия более чем 280 федеральными законами изменений как в отдельные процессуальные нормы, так и целые институты, включая процессуальные правила о возможности производства на этапе проверки сообщения о преступлении более де- сяти следственных и иных процессуальных действий, выделении следственного аппарата из органов прокуратуры и образовании Следственного комитета Российской Федерации, дифференциации процессуальных полномочий между прокурором и руководителем следственного органа, введении в 
число участников уголовного судопроизводства на стороне обвинения начальника подразделения дознания и начальника органа дознания и др., а также анализа результатов мониторинга действия кодекса и мнения ведущих российских процессуалистов и практикующих сотрудников в лице следователей и дознавателей сформировано авторское видение поступательного развития российского уголовно-процессуального законодательства.

Современное состояние российского уголовно-процессуального законодательства автором ${ }^{1}$ рассматривается с учетом эффективности реализации положений ст. 6 УПК РФ о назначении уголовного судопроизводства, призванной обеспечить защиту прав и законных интересов как лиц и организаций, пострадавших от преступлений, так и личности от незаконного и необоснованного обвинения, осуждения, ограничения ее прав и свобод.

Особое внимание автором уделяется дискуссионности содержания основных положений УПК РФ. При этом внесение в кодекс за двадцать лет столь значительного количества изменений, безусловно, не свидетельствует об идеальности закона, что дает почву для многочисленных критических высказываний со стороны ученых-процессуалистов и практикующих юристов.

В частности, профессор Л. В. Головко, характеризуя принятый в 2001 г. УПК РФ, отмечает, что кодекс «не только не стабилизировал отечественный уголовный процесс постсоветского образца, но, скорее, его "размыл" и дестабилизировал. При этом объяснение "эффекта размывания" неким "динамизмом", присущим нашему времени, по его мнению, вряд ли может быть воспринято, поскольку оно далеко от истины, как далеки от нее и сами претензии на какойто особый динамизм нашего времени» [13, с. 3-5].

Однако с данным утверждением согласиться не представляется возможным, в том числе и по причине того, что к вопросам законотворческой деятельности ему приходилось обращаться еще в конце 80-х гг. прошлого века, когда процесс подготовки и принятия законопроектов занимал годы.

\footnotetext{
${ }^{1}$ До 2007 г. Б. Я. Гаврилов занимал должность заместителя начальника Следственного комитета при МВД России, с 1997 г. входил в состав рабочей группы при Комитете по законодательству Государственной Думы Российской Федерации по подготовке проекта и принятию УПК РФ, а также его мониторингу.
}

Объяснение причин внесения в уголовнопроцессуальное законодательство столь значительного количества изменений видится, с одной стороны, в значительно возросших потребностях правоприменительной практики в части совершенствования процессуальных правил предварительного расследования и судебного разбирательства, подтверждение чему будет приведено далее в статье, а с другой - в стремительном развитии правоотношений в сфере уголовного судопроизводства.

В качестве классического примера внесения в УПК РФ изменений, обусловленных потребностями правоприменительной деятельности, следует привести принятие Федерального закона от 05.06.2007 № 87Ф3 «О внесении изменений в Уголовно-процессуальный кодекс Российской Федерации и Федеральный закон "О прокуратуре Российской Федерации"», согласно положениям которого следователи прокуратуры были выведены из подчинения прокуроров, и в этой связи процессуальные полномочия по руководству следствием были переданы от прокурора руководителю следственного органа с сохранением в полном объеме его надзорной функции. О необходимости этого неоднократно высказывались представители научного сообщества, а накануне данной реформы руководством Генеральной прокуратуры Российской Федерации при докладе Президенту Российской Федерации В. В. Путину была признана необходимость возложения полномочий по процессуальному руководству следствием и надзору за ним на двух заместителей Генерального прокурора Российской Федерации, что потребовало бы реализации этого предложения до районного уровня, в силу чего повлекло отказ от осуществления этого еще на стадии подготовки Генпрокуратурой России соответствующего приказа.

Этим же законом из УПК РФ исключены полномочия прокурора по согласованию постановления должностного лица органа предварительного расследования или органа дознания о возбуждении уголовного дела. Действие в течение пяти лет данного положения оказало негативное влияние на деятельность следователя, дознавателя по своевременному возбуждению уголовного дела и ограничивало возможности по собиранию доказательств в целях раскрытия преступлений по горячим следам, а у про- 
курора также было изъято право на возбуждение уголовного дела, которое, как свидетельствует правоприменительная практика, он использовал в единичных случаях.

О необходимости реформирования в этой части досудебного производства свидетельствуют приведенные ниже статистические данные о результатах следственной работы по реализации положений указанного федерального закона от 05.06.2007 № 87-
ФЗ, позволяющие сделать вывод о более высоком уровне процессуального контроля, что нашло свое отражение:

а) в улучшении показателей законности в деятельности органов предварительного расследования, в значительном сокращении числа лиц, оправданных судами, в том числе содержащихся под стражей (диаграмма 1);

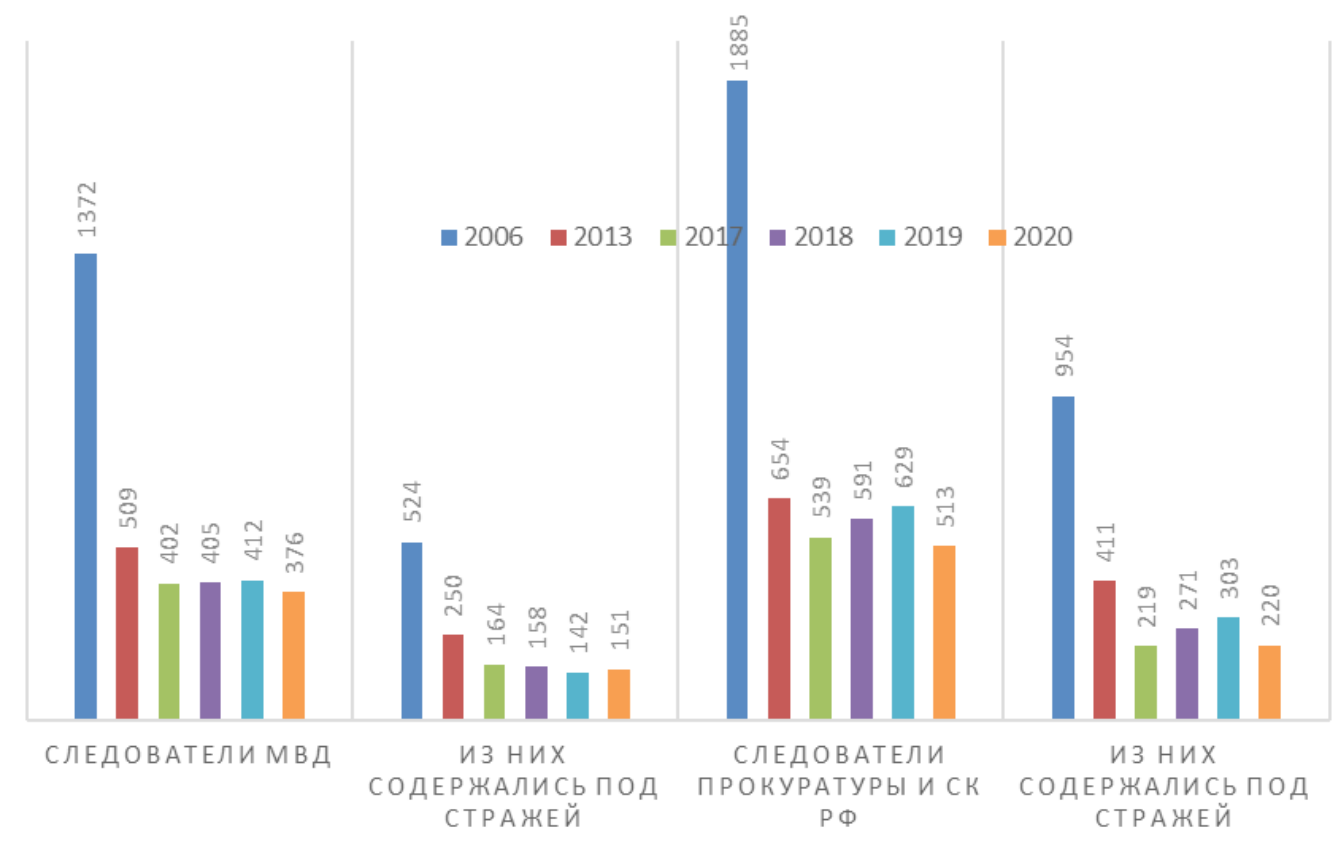

Диаграмма 1. Сведения о числе оправданных судом лиц и незаконно, необоснованно содержавшихся под стражей (за 2006, 2013, 2017-2020 гг.)

б) усилении надзорной функции прокуро- прокурором следователям как органов внура за качеством расследования, увеличении тренних дел, так и СК РФ (диаграмма 2); количества уголовных дел, возвращенных

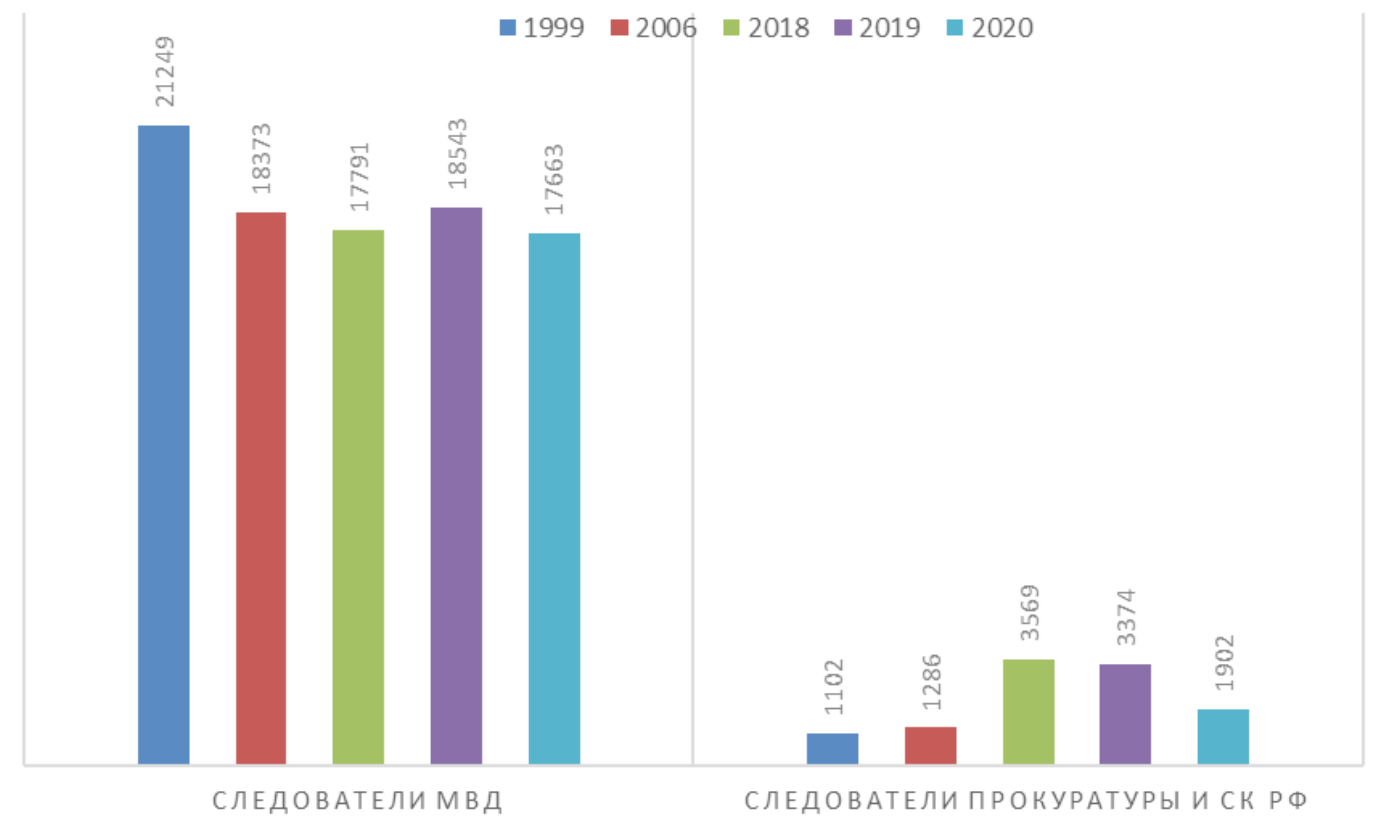

Диаграмма 2. Количество возвращенных прокурором уголовных дел для дополнительного расследования 


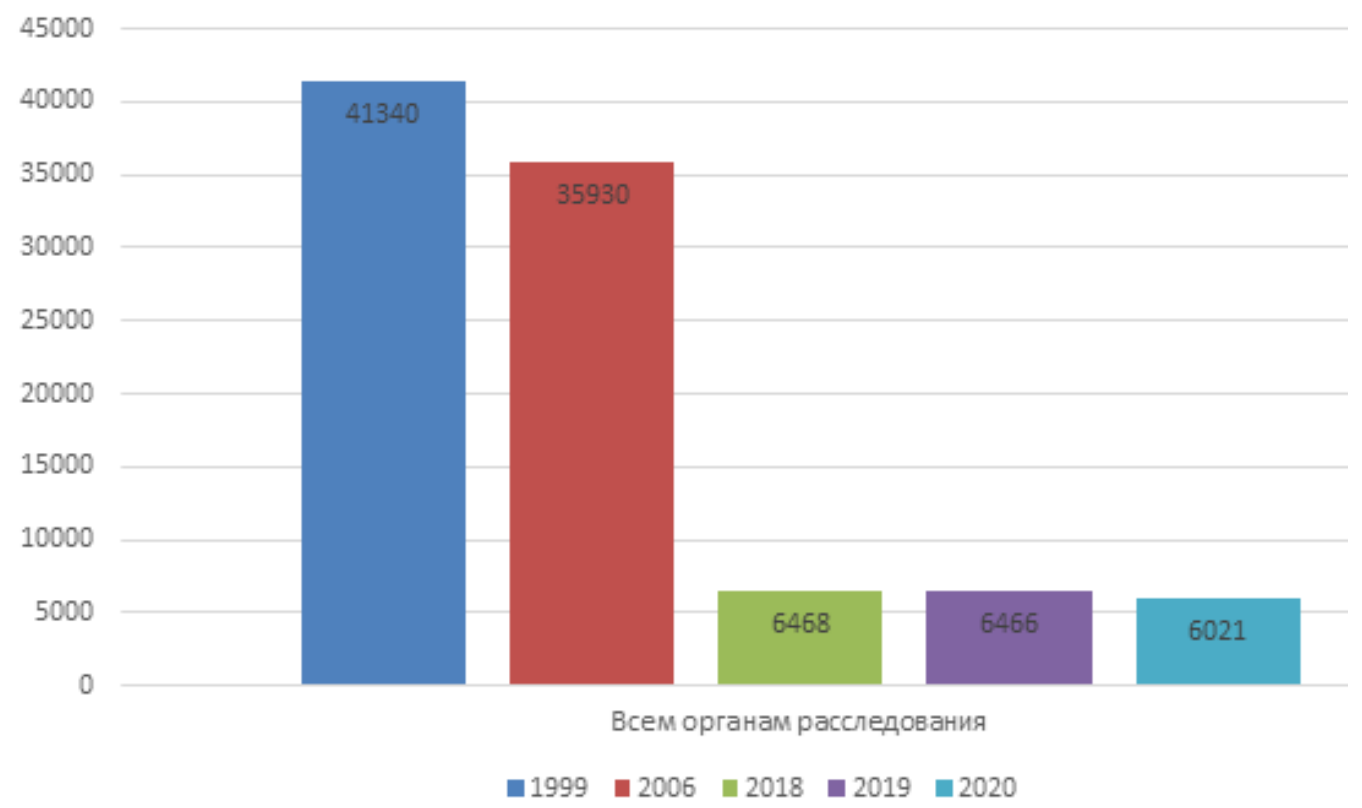

Диаграмма 3. Количество возвращенных дел судом для доследования (до 1 июля 2002 г.) и судом прокурору в порядке ст. 237 УПК РФ

в) обеспечении сокращения количества дел, возвращенных судом прокурору в порядке ст. 237 УПК РФ (диаграмма 3) [8].

Также профессор Л. В. Головко, говоря о качестве уголовно-процессуального законодательства, отмечает, что всякая кодификация прекращает действие старого юридического порядка и дает рождение новому, которое связано с качеством самой уголовно-процессуальной кодификации, но последняя крайне эклектична и неудачно пытается копировать априори несочетаемые с российской системой права англоамериканские подходы, которые стремятся представить уголовный процесс в виде рыночного «состязания» государства со своими гражданами [13].

Приведенный тезис, поддерживаемый рядом российских ученых, не подтвержден какими-либо аргументами, хотя, действительно, по предложению одного из членов рабочей группы в проект кодекса включена норма (ч. 6 ст. 234 УПК РФ в редакции 2001 г.), заимствованная из процессуального законодательства США, о невозможности удовлетворения заявленного стороной защиты в ходе судебного разбирательства ходатайства о вызове следователя для установления алиби подсудимого, если данное ходатайство заявлялось на предварительном следствии и было отклонено. Однако из УПК РФ эта норма вскоре была исключена.

Одновременно в части критических высказываний в адрес УПК РФ согласимся с мнением С. Б. Россинского, который о законодательных тенденциях высказывается в том ключе, что они нередко направлены на «гиперформализацию уголовно-процессуального права, в стремлении узаконить (в узком смысле) более широкий круг применяемых в ходе предварительного расследования и судебного разбирательства правил поведения, чем требует здравый смысл, превращая УПК в некий административный регламент» [19, с. 42].

При этом анализ изменений, которые претерпел кодекс за двадцать лет его действия, позволяет утверждать, что основанием для многих из них была необходимость выполнения решений Конституционного Суда Российской Федерации, Европейского Суда по правам человека (ЕСПЧ) и еще в большей степени востребованность со стороны правоприменителей. Одновременно нет оснований не согласиться с тем, что отдельные изменения в УПК РФ выражали популистский характер их авторов, представляющих в первую очередь органы законодательной власти, а некоторые, в том числе внесенные высшей судебной инстанцией страны, носили характер контрреформ в силу их противоречивости ряду основополагающих положений принятого УПК РФ, например о порядке изложения доказательств в обвинительном заключении, фактическом расширении института возвращения уголовного дела прокурору [8]. По сути, аналогичные претензии высказал 
профессор В. П. Божьев и в адрес Конституционного Суда Российской Федерации [3].

Анализ внесенных в УПК РФ поправок свидетельствует, что одна из причин их многочисленности заключалась в компромиссных решениях законодателя в процессе подготовки и принятия кодекса, поскольку в тот период не были реализованы предложения членов рабочей группы при Комитете по законодательству Государственный Думы в части дифференциации процессуальных полномочий между прокурором и руководителем следственного органа, о чем сказано выше, об изменении процессуальных правил начала расследования, введении в досудебное производство начальника подразделения дознания и ряда других изменений, что законодатель был вынужден реализовывать в последующие годы [10].

К факторам, обусловившим внесение в УПК РФ столь значительного количества изменений, считаем возможным отнести и непоследовательную позицию законодателя, сохранившего за прокурором Федеральным законом от 18.12.2001 № 177-Ф3 «О введении в действие Уголовно-процессуального кодекса Российской Федерации" до 1 января 2004 г. права санкционирования следственных действий, ограничивающих конституционные права граждан, в том числе и заключение под стражу, а Федеральным законом от 29.12.2001 № 183-Ф3 «О внесении изменения в статью 97 Уголовно-процессуального кодекса РСФСР» представление Генеральному прокурору Российской Федерации и его заместителям права на продление срока содержания обвиняемых под стражей. Конституционный Суд Российской Федерации в своем Постановлении от 14.03.2002 № 6-П «По делу о проверке конституционности статей 90, 96, 122 и 216 Уголовно-процессуального кодекса РСФСР в связи с жалобами граждан С. С. Мартынова и С. В. Пустовалов» признал не соответствующими ст. 21, 22, 23, 25 Конституции Российской Федерации указанные выше положения, что потребовало от законодателя внесения в УПК РФ еще до вступления его в действие целого блока соответствующих изменений (Федеральный закон от 29.05.2002 № 58-Ф3 «О внесении изменений и дополнений в Уголовно-процессуальный кодекс Российской Федерации»).

Отметим и необходимость выполнения Российской Федерацией ряда решений Ев- ропейского Суда по правам человека. Так, Федеральным законом от 30.04.2010 № 69Ф3 «О внесении изменений в отдельные законодательные акты Российской Федерации в связи с принятием Федерального закона "О компенсации за нарушение права на разумный срок судопроизводства или права на исполнение судебного акта в разумный срок"» в кодекс включена нормапринцип - ст. 6.1 УПК РФ «Разумный срок уголовного судопроизводства», чем реализованы решения ЕСПЧ от 15.01.2009 по делу «Бурдов» и «Бурдов против Российской Федерации (№ 2)» (жалоба № 33509/04). И только в одну эту норму (ст. 6.1 УПК РФ) в последующем были внесены изменения пятью федеральными законами с целью уточнения момента исчисления разумных сроков, что свидетельствует в целом о реальной необходимости многочисленных изменений кодекса.

Как отмечено выше, абсолютное большинство изменений было обусловлено потребностями правоприменительной практики.

Одновременно анализ эффективности результатов действия УПК РФ в досудебном производстве свидетельствует о необходимости дальнейшего реформирования: касается оно в первую очередь стадии возбуждения уголовного дела, наличие которой повлекло двукратное снижение в 2020 г. по отношению к 2006 г. количества возбужденных уголовных дел и увеличение за этот период на 2,3 млн количества процессуальных решений следователя, дознавателя, органа дознания об отказе в возбуждении уголовного дела при незначительном снижении числа зарегистрированных заявлений и сообщений о преступлениях [4]. Указанная процессуальная деятельность фактически ограничивает право граждан на их доступ к правосудию и возмещению причиненного им совершенным преступлением ущерба (ст. 52 Конституции Российской Федерации) (диаграмма 4).

Предложения автора, поддерживаемые и другими учеными [12; 16], об исключении ст. 146 и 148 УПК РФ вносятся с учетом решений Конституционного Суда Российской Федерации (определение от 18.07.2006 № 343-О «Об отказе в принятии к рассмотрению жалобы гражданина Лазарянца Андрея Эммануиловича на нарушение его конституционных прав статьями 241 и 242 Уголовного кодекса Российской Федера- 


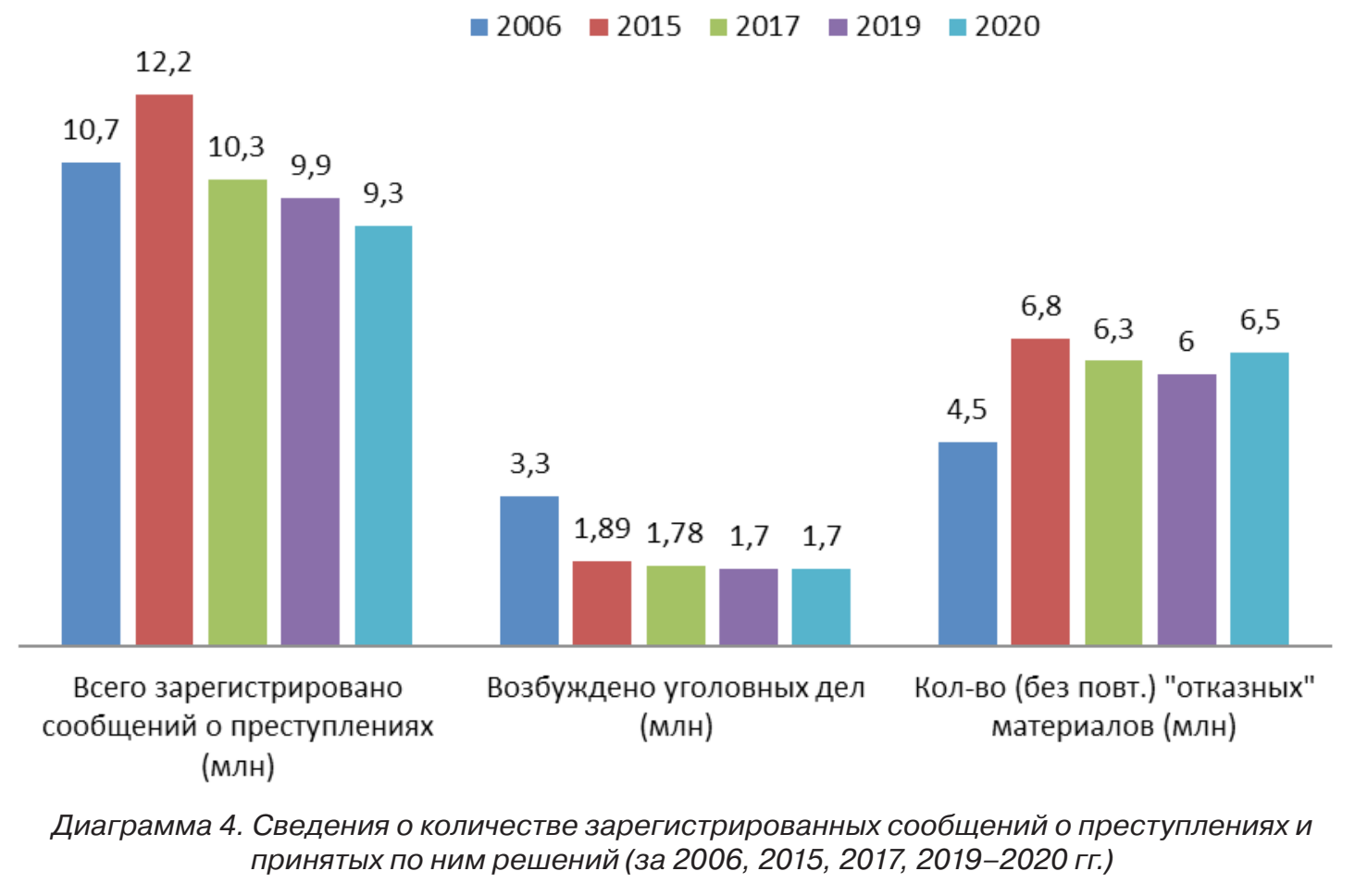

ции, частью первой статьи 46, статьями 57, 80, частью первой статьи 108, статьями 171, 172 и 195 Уголовно-процессуального кодекса Российской Федерации») и позиции Верховного Суда Российской Федерации, отмеченной В. В. Кожокарем [14], в соответствии с которыми при выявлении по расследуемому уголовному делу нового эпизода преступной деятельности или выявлении соучастника преступления следователь должен возбудить новое уголовное дело, которое в последующем соединить с основным уголовным делом, что противоречит ранее принятым решениям данных судебных органов, а также многолетней практике расследования и правовому содержанию остающейся неизменной на протяжении шестидесяти лет нормы о возбуждении уголовного дела.

Вместе с тем существуют и иные точки зрения, включающие сохранение стадии возбуждения уголовного дела [6; 21] или выражающие более нейтральную позицию [5; 17].

В последующие годы по настоянию правоприменителя Федеральным законом от 04.03.2013 № 23-Ф3 «О внесении изменений в статьи 62 и 303 Уголовного кодекса Российской Федерации и Уголовно-процессуальный кодекс Российской Федерации» был, как отмечено выше, значительно расширен перечень следственных и иных процессуальных действий, производство которых возможно в ходе проверки заявления, сообщения о преступлении, к которым законодатель отнес: получение объяснения и образцов для сравнительного исследования, истребование предметов и документов, назначение и производство судебной экспертизы и ряд других, что предоставляет сегодня следователям, дознавателям, иным должностным лицам органов дознания право собирания доказательств в стадии возбуждения уголовного дела. Данным законом в досудебное производство введена также сокращенная форма дознания, предусматривающая возможность расследования в более сжатые сроки и собирания доказательств в объеме, достаточном для осуществления судопроизводства по уголовному делу.

Существенная роль в обеспечении качества расследования уголовных дел в форме дознания в общем порядке и в сокращенной форме принадлежит Федеральному закону от 06.06.2007 № 90-ФЗ «О внесении изменений в Уголовно-процессуальный кодекс Российской Федерации», которым в качестве участника уголовного процесса в кодекс был введен начальник подразделения дознания, а в последующем и начальник органа дознания, институт досудебного соглашения о сотрудничестве и ряд других.

Наряду с досудебным производством существенные изменения претерпело и су- 
дебное производство. Так, с 1 января 2013 г. апелляционный порядок пересмотра приговоров был распространен и на федеральные суды, с 1 июня 2018 г. подсудность суда присяжных распространена на федеральные суды районного, городского уровней, а с 31 октября 2019 г. в судебную систему включены пять апелляционных и девять кассационных судов общей юрисдикции, что имеет своей целью повышение уровня обеспечения прав и законных интересов участников производства по уголовному делу.

Вместе с тем при построении модели современного УПК РФ представителям научной общественности, правоприменителям и законодателю не удалось преодолеть сложившиеся еще в рамках действия УПК РСФСР заформализованность и забюрократизированность уголовно-процессуального закона, прямым следствием чего является низкая эффективность досудебного производства. Данный вывод нами сделан на том основании, что количество направленных, например, следователями органов внутренних дел в суд уголовных дел из числа возбужденных сократилось более чем на треть (с 36 \% в 1991 г. до 22 \% в 2020 г.) (например, приговор Богородицкого районного суда Тульской области № 1-1/2016 1-124/2015 от 18 января 2016 г. по делу № 1-1/2016) [9; 11].

Такое состояние уголовного судопроизводства профессор А. С. Александров [2] оценивает как коренной порок отечественной правовой модели и предлагает отказаться от предварительного следствия с переходом на «прокурорское» дознание. С этим утверждением возможно было бы и согласиться, если бы к этому была готова судебная система. Более того, такие революционные преобразования в условиях России способны разрушить систему предварительного следствия, без которого судебная система останется «без работы». По этой же причине не получили одобрения и предложения о введении адвокатского (параллельного) расследования.

Необходимость совершенствования уголовно-процессуального законодательства обусловлена, как отмечено выше, тем, что эффективность в целом уголовного судопроизводства не соответствует требованиям сегодняшнего дня, требует пересмотра отдельных процессуальных институтов.

Эти изменения должны быть направлены:

- на приведение положений ст. 162 УПК РФ, предоставляющей органам предвари- тельного следствия право продления срока предварительного следствия без его ограничения, в соответствие с нормой-принципом (ст. 6.1 УПК РФ) о разумном сроке уголовного судопроизводства, который, исходя из содержания постановления Пленума Верховного Суда Российской Федерации от 29.03.2016 № 11-П, не должен превышать по уголовным делам четырех лет. Требуется пересмотр и положения ч. 1 ст. 162 УПК о двухмесячном первоначальном сроке расследования, перешедшей из УПК РСФСР 1922 г.;

- увеличение первоначального (два месяца) срока содержания обвиняемого под стражей, в который, исходя из положений ч. 1 и ч. 1.1 ст. 221 УПК РФ, входят от 10 до 30 суток для утверждения прокурором обвинительного заключения по поступившему к нему уголовному делу (вместо 5 суток по УПК РФ 2001 г.) и еще 14 суток для принятия судом (судьей) соответствующего решения в порядке ч. 1 ст. 227 УПК РФ. Данное предложение учитывает и опыт государств с устоявшейся системой правосудия, где первоначальный срок содержания лица составляет от 120 до 180 дней, а по УПК Италии - 6 месяцев с возможностью его сокращения судом по обращению прокурора или стороны защиты;

- пересмотр процессуальных правил предъявления обвинения, нормы которого на протяжении десятилетий обеспечивали право обвиняемого на защиту путем допуска адвоката к участию в уголовном деле с момента предъявления обвинения. Однако сегодня с принятием указанного выше федерального закона от 04.03.2013 № 23-Ф3 участие защитника предусмотрено уже с момента проверки в отношении лица сообщения о преступлении, то есть еще до возбуждения уголовного дела. В действующем УПК РФ фактически отсутствуют и различия в правовом положении подозреваемого (ст. 46) и обвиняемого (ст. 47), за исключением этапа окончания уголовного дела. Аргументом считаем то, что в суд за годы действия УПК РФ без классического предъявления обвинения направлено более 5 млн уголовных дел, расследованных в форме дознания. При этом никто из осужденных не обратился ни в Конституционный Суд Российской Федерации, ни в Европейский Суд по правам человека с жалобой об ограничении его конституционного права на защиту от обвинения. Сле- 
дует учитывать и позицию ЕСПЧ по делу Экле (решение от 15.08.1982 по делу «Экле (Eckle) против Федеративной Республики Германии» (жалоба № 8130/78)) и ряд других его решений о том, что обвинение есть обоснованное подозрение, позволяющее осуществлять от имени государства уголовное преследование.

В свою очередь, С. Б. Россинский обращает внимание, что в дореволюционном законодательстве России под обвиняемым понимался некий субъект, в отношении которого осуществлялось предварительное следствие в целях установления его причастности к преступлению. А его появление в уголовном деле не предопределялось изданием специального следственного акта. Иными словами, дореволюционный обвиняемый более напоминал сегодняшнего подозреваемого [17; 18]. Институт предъявления лица в качестве обвиняемого появился в УПК РСФСР 1922 г., второй раздел которого содержал специальную гл. XI «Предъявление обвинения и допрос» [15].

С реорганизацией института предъявления обвинения непосредственно связан и вопрос о полномочиях суда по изменению обвинения, который десятки лет служил основным средством устранения ошибок и недостатков предварительного расследования. Его негативным последствием по УПК РСФСР было ежегодное возвращение судом от 45 до 56 тыс. уголовных дел следователям, дознавателям для производства по ним дополнительного расследования, что увеличивало срок расследования и последующего судебного разбирательства от 3 до 6 месяцев, а по отдельным уголовным делам - от 1,5 до 2 лет, а также делало невозможным перепредъявление обвинения в суде на более тяжкое.

При разработке предложений по совершенствованию данного института исходим из того, что непосредственное исправление в суде дефектов и несоответствий установленным фактам допускается законодательством и судебной практикой Англии, Уэльса и Шотландии и других государств. Например, в Италии в ходе судебного следствия прокурор при соблюдении права обвиняемого на защиту и других условий вправе изменить исходное обвинение на более тяжкое или существенно отличающееся от первоначального путем дополнительного уведомления или нового изложения деяния (ст. 517, 519 УПК Италии). Согласно ст. 732
Уголовно-процессуального закона Испании изменение предварительной квалификации стороной обвинения является самостоятельным этапом судебного разбирательства, в котором для необходимости усиления обвинения предусмотрено отложение слушания дела по просьбе защиты для подготовки доказательств в опровержение измененного обвинения. Возможность изменения в судебном разбирательстве обвинения на более тяжкое без возвращения уголовного дела прокурору предусмотрена ст. 301 УПК Республики Беларусь и ст. 340341 УПК Казахстана.

Непременными условиями соответствия предлагаемой нами и рядом других ученых процедуры изменения обвинения в суде на более тяжкое должны быть инициирование этого вопроса исключительно стороной обвинения и создание достаточных гарантий обеспечения права обвиняемому на защиту от нового обвинения. Предлагаемые процедуры изменения прокурором обвинения на более тяжкое непосредственно в ходе судебного производства с правом представить суду дополнительные доказательства видятся в следующем: уголовное дело остается под контролем суда и исключается его разрешение несудебными органами; движение уголовного дела сохраняет поступательный характер и, как следствие, существенно сокращаются сроки производства по делу; не ограничивается право участников уголовного процесса на их доступ к правосудию; налицо процессуальная экономия, так как отпадает необходимость в производстве дополнительных процессуально-следственных действий и повторного судебного рассмотрения дела; в большей степени реализуется право государственного обвинителя на свободу оценки доказательств, повышается объективность его позиции в деле; суд не втягивается в осуществление обвинительной функции, не нарушается принцип состязательности судопроизводства; в большей степени обеспечивается объективность и беспристрастность суда.

В числе проблем совершенствования УПК РФ следует отметить замену дознания в сокращенной форме, которое как по срокам расследования, так и по объему собираемых доказательств ничем сегодня не отличается от дознания в общем порядке и даже превосходит его по количеству принимаемых дознавателем решений. Вместо 
него предлагается протокольная форма предварительного расследования, производимого в течение 48 часов в отношении конкретного лица при его задержании с поличным и признании им факта совершения преступного деяния. Данная форма расследования, по нашему мнению, не должна предусматривать процедуру возбуждения уголовного дела. Предлагается также законодательным путем ограничить перечень обязательных следственных действий допросом заподозренного в совершении преступления лица, а также потерпевшего или свидетеля (при отсутствии потерпевшего) совершенного преступления. Закон должен предусматривать обязательное задержание такого лица на срок до 48 часов, в течение которых расследование должно быть завершено. При поступлении уголовного дела в суд срок задержания продлевается до 72 часов, необходимых для осуществления судебного разбирательства. Такие сокращенные правила расследования содержат нормы УПК ФРГ, Итальянской Республики и ряда других государств Европы.

Относительно обсуждаемой сегодня проблемы возвращения прокурору полномочий по возбуждению уголовного дела следует уточнить, что для ее разрешения достаточно лишь изменить редакцию п. 4 ч. 1 ст. 140 УПК РФ, установив, что «по постановлению прокурора о направлении материалов в орган расследования для решения вопроса об уголовном преследовании следователь, дознаватель незамедлительно (в течение 24 часов) возбуждает уголовное дело, за исключением случаев, препятствующих началу его производства». Такие случаи предусмотрены ч. 1 ст. 24 (п. 3, 5, 6) и ч. 1 ст. 27 УПК РФ (п. 3-6).

В качестве самостоятельного некоторыми представителями научной общественности [1] выдвигается требование о возвращении прокурору полномочий по согласованию обращений следователей в суд о заключении подозреваемых, обвиняемых под стражу, поскольку передача этой функции руководителю следственного органа якобы повлекла рост нарушений законности. О необоснованности этих требований можно судить через приведенные статистические данные о значительном сокращении с передачей этих полномочий от прокурора руководителю следственного органа числа ежегодно заключаемых под стражу граждан (диаграмма 5).

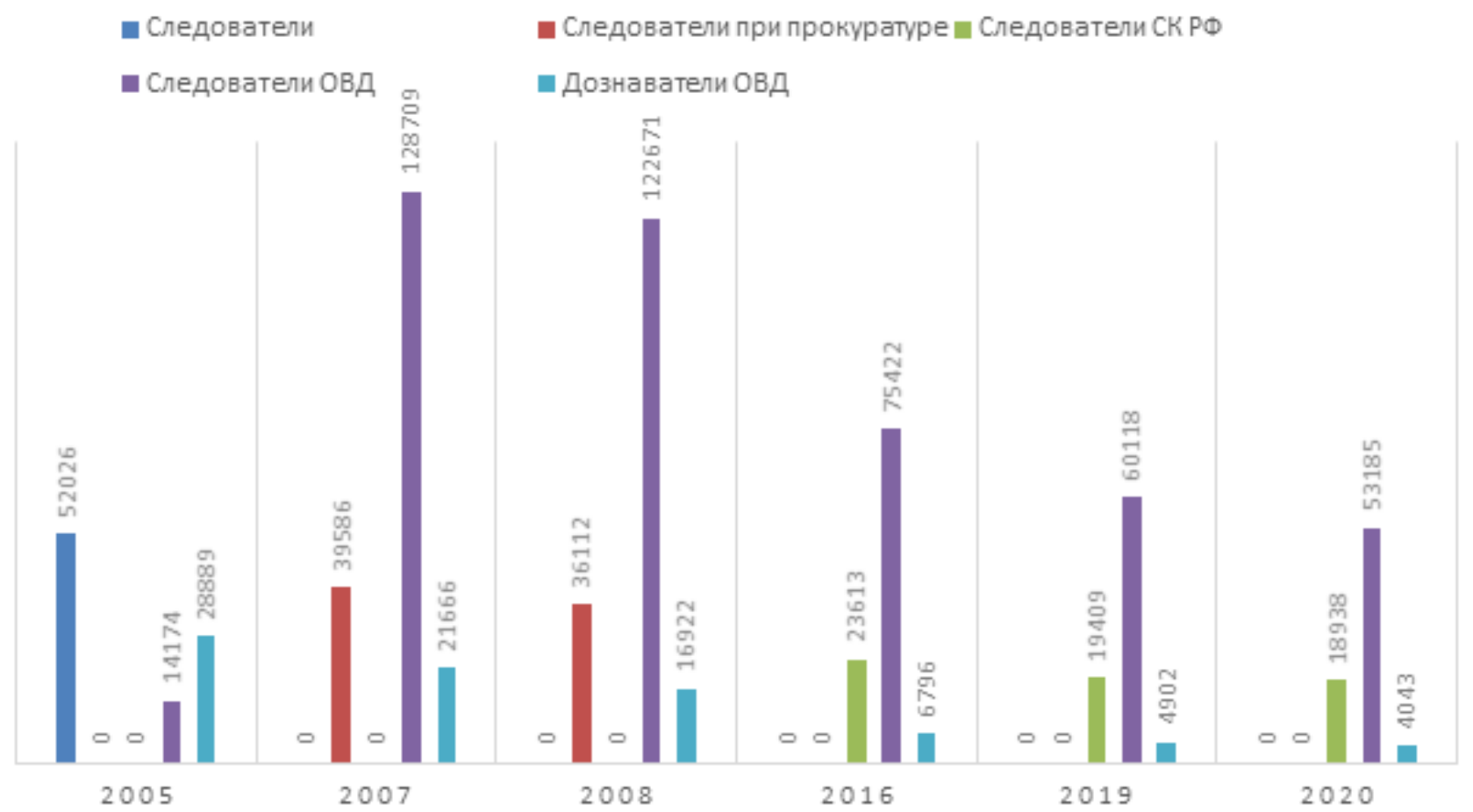

Диаграмма 5. Сведения о числе заключенных под стражу подозреваемых, обвиняемых по ходатайству следователя, дознавателя (за 2005-2008 гг., 2016-2020 гг.) 
Кроме того, в числе аргументов за возвращение прокурору полномочий по процессуальному руководству следователями (для объективности следует указать, что Генеральный прокурор Российской Федерации И. В. Краснов заявил о достаточности этих прав для обеспечения должного уровня надзора за следствием) представители научной общественности нередко выдвигают тезис о том, что следователи как органов внутренних дел, так и Следственного комитета Российской Федерации нередко игнорируют требования прокуроров, заявленные в соответствии п. 3 ч. 2 ст. 37 УПК РФ, об устранении нарушений федерального законодательства, допущенных в ходе предварительного следствия.

Однако, по данным Генпрокуратуры России (отчет по форме 555), в 2017-2020 гг. прокурорами в порядке п. 3 ч. 2 ст. 37 УПК РФ направлено следователям Следственного комитета Российской Федерации от 42 тыс. до 46 тыс. требований, из которых было удовлетворено 97-98 \%. Из выявленных прокурорами от 105 тыс. до 125 тыс. за этот же период нарушений федерального законодательства по уголовным делам, расследованным следователями органов внутренних дел, удовлетворено $99 \%$. По органам дознания в системе МВД России удовлетворено более 99 \% таких требований.

С учетом факторов, приведенных в этой статье и иных публикациях, авторская позиция [7] заключается в широком обсуждении в научном сообществе и среди правоприменителей с последующим доведением до законодателя предложений, предусматривающих внесение рассмотренных изменений. Задача состоит не в создании нового уголовно-процессуального кодекса, а в разработке доктрины досудебного производства, призванной отразить произошедшие в социально-политической, экономической и правовой жизни российского государства изменения, чему сегодня в значительной мере препятствует устоявшийся в нашем сознании стереотип незыблемости названных выше уголовно-процессуальных институтов, не позволяющих обеспечить эффективность уголовного судопроизводства.

\section{СПИСОК ЛИТЕРАТУРЫ}

1. Александров, А. И. Выступление на круглом столе в Совете Федерации 19 ноября 2020 г. «Проблемы законодательного регулирования правового положения прокурора и адвоката уголовном процессе» / А. И. Александров. URL: http://council.gov.ru/activity/activities/roundtables/?date=19.11.2020 (дата обращения: 12.09.2021).

2. Александров, А. С. О доктринальной модели уголовно-процессуального доказательственного права России / А. С. Александров // Вестник Нижегородской правовой академии. - 2015. - № 5 (5). - С. 7-10.

3. Божьев, В. П. «Тихая революция» Конституционного суда в уголовном процессе Российской Федерации / В. П. Божьев // Российская юстиция. - 2000. - № 10. - С. 9-11.

4. Божьев, В. П. Соответствует ли отказ в возбуждении уголовного дела идеологии современной уголовно-правовой политики России / В. П. Божьев, Б. Я. Гаврилов // Вестник Санкт-Петербургского университета МВД России. 2018. - № 2 (78). - С. 74-78.

5. Васюков, В. Ф. Проблемные вопросы возбуждения уголовных дел на современном этапе : монография / В. Ф. Васюков, Е. В. Марковичева. - Москва : Проспект, 2016. - 80 с.

6. Волеводз, А. Г. Упразднение стадии возбуждения уголовного дела: цена вопроса / А. Г. Волеводз // Уголовный процесс. - 2014. - № 1. - С. 80-83.

7. Воскобитова, Л. А. Уголовное судопроизводство как социальная технология / Л. А. Воскобитова // Уголовное судопроизводство. - 2021. - № 2. - С. 6-17.

8. Гаврилов, Б. Я. Идеология формирования современного досудебного производства / Б. Я. Гаврилов // Труды Академии управления МВД России. - 2018. - № 1. - С. 22-28.

9. Гаврилов, Б. Я. Отвечает ли современное досудебное производство реалиям борьбы с преступностью? / Б. Я. Гаврилов // Академическая мысль. - 2019. - № 3 (8). - С. 98-102.

10. Гаврилов, Б. Я. XX лет российскому уголовно-процессуальному закону: соответствует ли он научным воззрениям и требованиям правоприменителя / Б. Я. Гаврилов // Законы России: опыт, анализ, практика. - 2021. - № 6. C. 4-14.

11. Гаврилов, Б. Я. Эффективность досудебного производства / Б. Я. Гаврилов // Уголовное судопроизводство. 2017 - № 2. - С. 19-26.

12. Гирько, С. И. О некоторых проблемных вопросах процессуальной регламентации ускоренного досудебного производства / С. И. Гирько // Российский следователь. - 2010. - № 15. - С. 14-16.

13. Головко, Л. В. УПК Российской Федерации 2001 года как кодификация: «эффект кристаллизации» или «эффект размывания»? / Л. В. Головко // Законы России: опыт, анализ, практика. - 2021. - № 6. - С. 3-5.

14. Кожокарь, В. В. Возбуждение уголовного дела: правовая позиция Конституционного Суда и Верховного Суда РФ / В. В. Кожокарь // Труды Академии управления МВД России. - 2015. - № 1. - С. 20-22.

15. Никулина, Т. Г. История возникновения института привлечения лица в качестве обвиняемого и современные перспективы развития / Т. Г. Никулина // Вестник Удмуртского университета. - 2010. - Выпуск № 4. - С. 115-117. 
16. Россинский, С. Б. Возбуждение уголовного дела как автономная стадия российского уголовного судопроизводства: за и против / С. Б. Россинский // Вестник Уральского юридического института МВД России. - 2021. - № 3. C. $48-54$.

17. Россинский, С. Б. Дискуссия о сущности и правовой природе задержания подозреваемого продолжается... / С. Б. Россинский // Актуальные проблемы российского права. - 2018. - № 6 (91). - С. 134-145.

18. Россинский, С. Б. Привлечение в качестве обвиняемого - результат максимально полного расследования обстоятельств уголовного дела / С. Б. Россинский // Правда и закон. - 2021. - № 3. - С. 69-77.

19. Россинский, С. Б. УПК Российской Федерации: возрождение «высокого» предназначения уголовно-процессуальной формы или «памятка» для безграмотных правоприменителей / С. Б. Россинский // Законы России: опыт, анализ, практика. - 2021. - № 6. - С. 42.

20. Федоров, А.В.Нужна ли по делам о наркопреступлениях стадия возбуждения уголовного дела? / А. В. Федоров // Наркоконтроль. - 2017. - № 1. - С. 3-17.

21. Шадрин, В. С. Судьба стадии возбуждения уголовного дела / В. С. Шадрин // Законность. - 2015. - № 1. C. $47-51$.

\section{REFERENCES}

1. Aleksandrov A.I. Vystuplenie na kruglom stole v Sovete Federatsii 19 noyabrya 2020 g. "Problemy zakonodatel'nogo regulirovaniya pravovogo polozheniya prokurora i advokata ugolovnom protsesse" [Speech at the round table in the Federation Council on November 19, 2020 "Problems of legislative regulation of the legal status of the prosecutor and lawyer in criminal proceedings"]. Available at: http://council.gov.ru/activity/activities/roundtables/?date=19.11.2020 (accessed September 12, 2021).

2. Aleksandrov A.S. On the doctrinal model of criminal procedural evidentiary law of Russia. Vestnik Nizhegorodskoi pravovoi akademii=Bulletin of the Nizhny Novgorod Law Academy, 2015, no. 5 (5), pp. 7-10. (In Russ.).

3. Bozh'ev V.P. "Silent revolution" of the Constitutional Court in the Criminal Process of the Russian Federation. Rossiiskaya yustitsiya=Russian Justice, 2000, no. 10, pp. 9-11. (In Russ.).

4. Bozh'ev V.P., Gavrilov B.Ya. Does the refusal to initiate criminal proceedings correspond to the ideology of modern criminal law policy of Russia. Vestnik Sankt-Peterburgskogo universiteta MVD Rossii=Vestnik of the St. Petersburg University of the Ministry of Internal Affairs of Russia, 2018, no. 2 (78), pp. 74-78. (In Russ.).

5. Vasyukov V.F., Markovicheva E.V. Problemnye voprosy vozbuzhdeniya ugolovnykh del na sovremennom etape: monografiya [Problematic issues of initiation of criminal cases at the present stage: monograph]. Moscow, Prospekt. 2016. $80 \mathrm{p}$.

6. Volevodz A.G. Abolition of the stage of initiation of a criminal case: the price paid. Ugolovnyi protsess=Criminal Proceedings, 2014, no. 1, pp. 80-83. (In Russ.).

7. Voskobitova L.A. Criminal justice as a social technology. Ugolovnoe sudoproizvodstvo=Criminal Judicial Proceeding, 2021, no. 2, pp. 6-17. (In Russ.).

8. Gavrilov B.Ya. Ideology of the formation of modern pre-trial proceedings. Trudy Akademii upravleniya MVD Rossii=Proceedings of the Academy of Management of the Ministry of Internal Affairs of Russia, 2018, no. 1, pp. 22-28. (In Russ.).

9. Gavrilov B.Ya. Does the modern pre-trial proceedings answer the realities of fighting crime? Akademicheskaya mysl'=Academic Thought, 2019, no. 3 (8), pp. 98-102. (In Russ.).

10. Gavrilov B.Ya. Twenty years of the Russian criminal procedure law: whether it complies with scientific views and requirements of the law enforcement officer. Zakony Rossii. Opyt. Analiz. Praktika=Russian Laws: Experience, Analysis, Practice, 2021, no. 6, pp. 4-14. (In Russ.).

11. Gavrilov B.Ya. Pre-trial proceedings efficiency. Ugolovnoe sudoproizvodstvo=Criminal Judicial Proceeding, 2017, no. 2, pp. 19-26. (In Russ.).

12. Gir'ko S.I. O On certain controversial issues of procedural regulation of new prejudicial procedure. Rossiiskii sledovatel'=Russian Investigator, 2010, no. 15, pp. 14-16. (In Russ.).

13. Golovko L.V. The CPC of the Russian Federation as amended in 2001 as codification: "crystallization effect" or "blurring effect"? Zakony Rossii. Opyt. Analiz. Praktika=Russian Laws: Experience, Analysis, Practice, 2021, no. 6, pp. 3-5. (In Russ.).

14. Kozhokar' V.V. Initiation of legal proceedings: legal position of the Constitutional Court and Supreme Court of the Russian Federation. Trudy Akademii upravleniya MVD Rossii=Proceedings of the Academy of Management of the Ministry of Internal Affairs of Russia, 2015, no. 1, pp. 20-22. (In Russ.).

15. Nikulina T.G. History of the institution of attracting a person as an accused and modern development prospects. Vestnik Udmurtskogo universiteta=Bulletin of Udmurt University. Series Economics and Law, 2010, no. 4, pp. 115-117. (In Russ.). 16. Rossinskii S.B. Initiation of a criminal case as an autonomous stage Russian criminal procedure: pros and cons. Vestnik Ural'skogo yuridicheskogo instituta MVD Rossii=Bulletin of the Ural Law Institute of the Ministry of the Interior of the Russian Federation, 2021, no. 3, pp. 48-54. (In Russ.).

17. Rossinskii S.B. Discussion about the essence and legal nature of the suspect's detention continues. Aktual'nye problemy rossiiskogo prava=Actual Problems of Russian Law, 2018, no. 6 (91), pp. 134-145. (In Russ.).

18. Rossinskii S.B. Involvement as an accused is the result of the fullest possible investigation of the circumstances of the criminal case. Pravda i zakon=Truth and Law, 2021, no. 3, pp. 69-77. (In Russ.).

19. Rossinskii S.B. The CPC of the Russian Federation: revival of a "high" purpose of the criminal procedure form or "memo" for illiterate law enforcement officers. Zakony Rossii. Opyt. Analiz. Praktika=Russian Laws: Experience, Analysis, Practice, 2021, no. 6, p. 42. (In Russ.).

20. Fedorov A.V. Is there any need for case institution stage in drug-related crimes? Narkokontrol'=Narkokontrol, 2017 , no. 1, pp. 3-17. (In Russ.).

21. Shadrin V.S. Fate of the criminal case initiation stage. Zakonnost'=Legality, 2015, no. 1, pp. 47-51. (In Russ.). 


\section{CВЕДЕНИЯ ОБ АВТОРЕ / INFORMATION ABOUT THE AUTHOR}

ГАВРИЛОВ БОРИС ЯКОВЛЕВИЧ - доктор юрИдических наук, профессор, профессор кафедры управления органами расследования преступлений Академии управления МВД России, г. Москва, Российская Федерация, ORCID: https://orcid.org/0000-0002-2529-491X, e-mail: profgavrilov@yandex.ru
BORIS YA. GAVRILOV - Doctor of Sciences (Law), Professor, professor of the Department of Administration of Investigative Bodies of the Academy of Management of the Ministry of Internal Affairs of Russia, Moscow, Russian Federation, ORCID: https://orcid.org/0000-0002-2529491X, e-mail: profgavrilov@yandex.ru 